Ks. Stanisław Garnczarski*

UPJPII w Krakowie Wydzial Teologiczny Sekcja w Tarnowie

\title{
ZNACZENIE INSPIRACJI RELIGIJNEJ W MUZYCE
}

Stowa klucze:

inspiracja religijna, wiara, sztuka, chorał gregoriański, msza, oratorium, pasja, kantata, Biblia, liturgia

Treść:

I. Chorał gregoriański

II. Wielogłosowość

III. Okres baroku

IV. Klasycyzm

V. Romantyzm

IV. Współczesność

Problematyka inspiracji religijnej w muzyce jest złożona i wieloaspektowa, zakorzeniona $\mathrm{w}$ rozległym obszarze wiary (wewnętrznym, głęboko osobistym) i sztuki. Z racji ograniczonej formy ukażemy tę problematykę w oparciu o wybrane przykłady, które zilustrują ogólnoeuropejskie zjawiska dokonujące się w historycznym rozwoju muzyki, zwłaszcza na polu jej religijnego charakteru. Patrząc bowiem na dzieje muzyki europejskiej, zauważamy, iż są to przede wszystkim dzieje muzyki religijnej. „Właściwie do końca XVI wieku muzyka była wyłącznie religijna, poza mało w tym czasie znaczącymi produkcjami ludowymi, które zresztą z muzyki religijnej również czerpały pełnymi garściami"1.

$\mathrm{Na}$ wstępie należy określić, jakie rodzaje inspiracji można brać w tym przypadku pod uwagę. Będą to na pewno inspiracje tekstem biblijnym, czy w ogóle religijnym (w tym na pewno liturgicznym) oraz inspiracje motywami muzyki liturgicznej czy w szerszym znaczeniu religijnej.

${ }^{*}$ Ks. Stanisław Garnczarski, dr nauk teologicznych w zakresie muzykologii, adiunkt na Wydziale Teologicznym Sekcja w Tarnowie UPJPII w Krakowie, autor oraz redaktor wielu publikacji muzykologicznych, teologicznych, w tym dotyczących głównie muzyki liturgicznej oraz kultury muzycznej.

${ }^{1}$ D. Krawczyk, Mała historia muzyki kościelnej, Kraków 2003, s. 8. 


\section{CHORAŁ GREGORIAŃSKI}

Ten własny śpiew liturgii rzymskiej Kościoła katolickiego wywodzi się ze śpiewu liturgicznego - kształtowanego w pierwszych wiekach chrześcijaństwa na podłożu muzyki synagogalnej, częściowo syryjskiej i bizantyjskiej, a także na gruncie greckiej muzyki późnoantycznej - posługującego się pierwotnie takimi formami, jak psalmy i hymny, z biegiem czasu, zwłaszcza po Edykcie mediolańskim z 15 czerwca 313 roku, wzbogaconego o nowe formy śpiewów mszalnych i brewiarzowych ${ }^{2}$. Przyjęcie w liturgii języka łacińskiego, uporządkowanie tych śpiewów pozwoliło na ich przyjęcie przez wszystkie Kościoły rytu rzymskokatolickiego. Z czasem nazwano ten śpiew od imienia papieża Grzegorza Wielkiego śpiewem gregoriańskim. Warto ten śpiew zauważyć, gdyż stanowił główny nurt muzyki średniowiecznej, a w okresie późniejszym z niego wyrosła wielogłosowość.

\section{WIELOGŁOSOWOŚĆ}

Pierwsze formy wielogłosowe, kształtujące się z wolna między wiekiem IX a XII, były przeważnie dwugłosowe i polegały na ujęciu w jednym z głosów melodii chorałowej - vox principalis (głos główny), zaś drugi głos wznosił się nad nim jako vox organalis i poruszał się w równoległych interwałach kwarty i kwinty. Z czasem vox organalis rozwijał się, stając się coraz bardziej niezależnym od vox principalis, a do tego dochodziły jeszcze kolejne głosy. Coraz to nowsze sposoby traktowania poszczególnych głosów doprowadziły do powstania polifonii, której najwybitniejszym przedstawicielem w szkole rzymskiej był jej twórca, Pierluigi da Palestrina (ok. 1525-1595). W swojej twórczości nawiązywał do flamandzkiej techniki polifonicznej (imitacja, kanon). W melodyce unikał chromatyki, stosując ścisłą diatonikę opartą na skalach kościelnych i śpiewach chorałowych (bardzo często czerpał cantus firmus $\mathrm{z}$ chorału). W tym miejscu należy się wyjaśnienie odnośnie do pojęcia cantus firmus. Otóż jest to struktura melodyczna (czyli fragment melodii) będąca podstawą kompozycji wielogłosowej. Do niej dokomponowywano głosy kontrapunktujące. Stanowiła ona melodię powstałą wcześniej, pochodzącą z różnych źródeł: 1) najczęściej chorału gregoriańskiego; 2) pieśni świeckiej; 3) chorału protestanckiego itp.

Kompozycje kościelne Palestriny obejmują ok. 100 mszy, ok. 500 motetów (4-12-głosowych) - w tym słynny cykl: Canticum canticorum skomponowany do tekstów biblijnych z Księgi Pieśni nad pieśniami, 68 offertoriów, lamentacje, litanie, Magnificat, słynne Improperia (Popule meus) mające swoje miejsce w wielkopiątkowym repertuarze Capelli sykstyńskiej ${ }^{3}$. Styl palestrinowski został ogłoszony na Soborze Trydenckim oficjalnym stylem Kościoła rzymskiego.

\footnotetext{
${ }^{2}$ Por. E. Hinz, Zarys historii muzyki kościelnej, Pelplin 2000, s. 12-13.

${ }^{3}$ Por. tamże, s. 74.
} 


\section{OKRES BAROKU}

Muzyka okresu baroku otworzyła się na nową formę - oratorium, które obok mszy jest najbardziej popularnym i najważniejszym gatunkiem europejskiej muzyki religijnej. Oratorium to epicka forma instrumentalnowokalna muzyki dramatycznej, na ogół z tekstem o tematyce religijnej, bez akcji scenicznej. Rozwinęło się ono na gruncie średniowiecznego dramatu liturgicznego i misterium. Jego początki wiążą się z działalnością św. Filipa Nereusza, który w domu modlitwy zwanym „oratorio” organizował nabożeństwa połączone ze śpiewem dialogowanych laud, rapresentatione, storia, esempio. Formę oratorium ostatecznie ustalił w XVII wieku G. Carissimi, przejmując wszystkie środki wykształcone na gruncie opery. W XVIII wieku szczyty w twórczości oratorium osiągnęli J.F. Haendel (22 oratoria: ST Izrael w Egipcie, Samson, Saul, Juda Machabeusz; inne: Mesjasz) i J.S. Bach (3 oratoria: na Boże Narodzenie, Wielkanoc i Wniebowstąpienie).

Drugą formą, która rozwinęła się szczególnie w baroku, jest pasja, stanowiąca odmianę oratorium. Jest ona utworem wokalno-instrumentalnym opartym na ewangelicznych opisach Męki Pańskiej, a także na tekstach religijnej poezji. Pasja powstała już w XII wieku, w ramach śpiewu chorału gregoriańskiego. Polegała na muzycznej recytacji ewangelicznego opisu męki, podzielonego na trzy partie: Chrystusa, narratora i thumu. Pierwsze wielogłosowe opracowania pasji pochodzą z początku XV wieku. W epoce baroku ubogacone współdziałaniem partii recytatywnych, aryjnych, chóralnych i instrumentalnych, doprowadzone zostały do szczytu swojego rozwoju. Reprezentują je dwie pasje J.S. Bacha: wg św. Mateusza i św. Jana.

Kolejną formą rozwiniętą w baroku jest kantata. Jest to wieloczęściowy utwór wokalno-instrumentalny składający się z arii, recytatywów, duetów, partii chóralnych i instrumentalnych. Od oratorium różni się mniejszymi rozmiarami i większą różnorodnością tekstów. J.S. Bach napisał ok. 200 kantat kościelnych, które były wykonywane po Ewangelii - przed kazaniem, a ich tematyka zaczerpnięta była z Ewangelii.

Nie można w tym miejscu pominąć muzyki organowej, której podstawowym gatunkiem w muzyce protestanckiej były w czasach Bacha kompozycje oparte na niemieckich pieśniach chorałowych. Największy zbiór kompozycji tego typu to Orgelbüchllein, zawierający 45 chorałów w liturgicznym porządku roku kościelnego. Muzyka organowa Bacha jest najwyższym szczytem polifonicznego kunsztu.

Kończąc o Bachu, nie można nie wymienić jego wielkiej Mszy h-moll, napisanej do tekstów liturgii katolickiej, mimo iż sam twórca był protestantem, a także miniaturowe oratorium: Magnificat (na pięciogłosowy chór, scholę, orkiestrę i organy).

Mówiąc o muzyce baroku w Polsce, chciałbym przywołać postać Grzegorza Gerwazego Gorczyckiego (ok. 1667 w Bytomiu - 1734 w Krakowie), kapłana i wykształconego muzyka, związanego przez dłuższą część swojego 
życia z katedrą wawelską w Krakowie. Tworzył zarówno polifoniczne kompozycje a capella w stylu palestrinowskim, jak i okazałe, pełne blasku dzieła wokalno-instrumentalne w barokowym stylu koncertującym. Przeważają jednak utwory a capella, oparte przeważnie na cantus firmus zaczerpniętym z chorału gregoriańskiego, a także polskich pieśni kościelnych. Do najdoskonalszych tego typu kompozycji należą m.in.: Missa Rorate, Missa paschalis (w obu kompozycjach jest wykorzystany materiał 7 pieśni: Wesoły nam dzień dziś nastat, Wstat Pan Chrystus, Chrystus Pan Zmartwychwstat, czy odnośnie do Mszy roratniej: Po upadku człowieka grzesznego, Urząd zbawienia ludzkiego, Zdrowaś bądź Maryja i Gwiazdo morza głębokiego). Opierając swą mszę paschalną na pierwszych trzech pieśniach, Gorczycki sięgnął do polskiej tradycji trwającej od XVI wieku, gdyż na tych samych pieśniach oparli swe msze paschalne Marcin Leopolita, Franciszek Lilius i Bartłomiej Pękiel. Wpływ chorału na melodykę poszczególnych fraz widzimy także w utworach bez cantus firmus. Jest to nawiązanie do zabiegów klasycznej szkoły rzymskiej, gdzie w utworach religijnych melodyka chorałowa bardzo silnie wpływała na kształtowanie wszelkiej melodyki. Charakterystyczne dla Gorczyckiego jest to, że sięgał on nie tylko do oficjalnych wersji chorału, lecz także do lokalnych wersji diecezji krakowskiej. Zmiany, jakim poddawał wykorzystywane wersje chorałowe, wynikały na ogół albo z wymogów techniki imitacyjnej, albo z wymogów tonalności dur-moll.

Pozostałe kompozycje Gorczyckiego to: Missa de Conceptione B.M.V, Ave Maria, Sepulto Domino. W stylu koncertującym utrzymane są motety: Laetatus sum (oparty na tekście Psalmu 121) i Illuxit sol oraz Completorium.

\section{KLASYCYZM}

Okres klasycyzmu cechuje się rozkwitem muzyki instrumentalnej (symfonia, koncert instrumentalny, kwartet, sonata). Muzyka religijna tworzona w tym okresie nosi cechy muzyki instrumentalnej tego okresu, a także znamiona świeckiej muzyki wokalno-instrumentalnej (wokalne partie solowe w stylu arii operowych, równoczesne wykonywanie dwóch różnych tekstów liturgicznych itp.). Muzykę religijną w tym okresie tworzyli głównie trzej klasycy wiedeńscy: J. Haydn, W.A. Mozart i L. van Beethoven.

Najstarszy klasyk - Haydn obok muzyki świeckiej, która zdominowała jego twórczość, komponował także muzykę religijną: oratoria, msze, motety $\mathrm{i}$ in. Znamy jego trzy oratoria: Powrót Tobiasza (w stylu neapolitańskim), Siedem ostatnich stów naszego Zbawiciela na krzyżu (pełna ekspresji kompozycja o dramacie Golgoty) i Stworzenie świata (oratorium to jest jak gdyby hymnem pochwalnym na cześć Boga i Jego dzieła stworzenia. Haydn napisał 14 mszy. Starał się w nich zastosować najbardziej odpowiednią interpretację tekstów liturgicznych. 
W.A. Mozart pozostawił także ogromny dorobek muzyki religijnej, mimo iż jeszcze większą część jego twórczości stanowiła muzyka świecka. Skomponował oratorium Dawid pokutujacy (oparte na melodyce Kyrie i Gloria z jego Mszy c-moll), 2 nieszpory, 7 offertoriów, graduale (Santa Maria, Mater Dei), 2 motety, 2 Regina coeli, Te Deum, Miserere, 4 litanie. Wśród jego kompozycji religijnych najliczniej reprezentowane są msze. Skomponował 19 mszy. Największą popularnością cieszy się Msza koronacyjna C-dur (1779), którą Mozart napisał prawdopodobnie dla uczczenia cudownego obrazu Matki Boskiej z Plain, koronowanego w 1751 roku. Msze Mozarta odznaczają się wielką ekspresją i bogatą inwencją melodyczną. Partie solowe przeciwstawione są znakomitym partiom chóralnym, utrzymanym nie tylko w fakturze homofonicznej, ale także polifonicznej. Bardzo popularne są dwie kompozycje Mozarta: Msza Requiem (dokończona przez jego ucznia F.X. Süssmayera) oraz motet Ave verum na chór mieszany i zespół smyczkowy.

Najmłodszy z klasyków wiedeńskich - L. van Beethoven skomponował nieco mniej utworów muzyki religijnej. Są to: oratorium Chrystus na Górze Oliwnej (1811), Msza C-dur (1807) oraz monumentalna Missa solemnis $D$-dur, którą sam uważał za główne dzieło swojego życia.

\section{ROMANTYZM}

Muzyka romantyczna, cechująca się pierwiastkiem subiektywnym, mająca wyrażać rozmaite uczucia i nastroje, rozwinęła się w I poł. XIX wieku. Te cechy odnajdujemy także w muzyce religijnej tego okresu, chociaż twórczość ta nawiązywała także do muzyki klasycznej. Widać to głównie w formie mszy klasycznej typu kantatowego czy też mszy symfonicznej. Spośród twórców romantycznych przywołajmy Franciszka Schuberta. Napisał on 6 łacińskich mszy, 4 Tantum ergo na chór mieszany, orkiestrę i organy, 5 Salve Regina, 2 Stabat Mater, kantatę Wiara, nadziej i mitość, Hymn do Ducha Świętego na chór męski $\mathrm{z}$ orkiestrą i in. Cechuje go dosyć swobodne traktowanie tekstów mszalnych. Bardzo interesujące są dzieła religijne Hectora Berlioza, np. oratorium biblijne Dziecięctwo Chrystusa (jest to trylogia zawierająca części zatytułowane: Sen Heroda, Ucieczka do Egiptu oraz Przybycie do Sais), dalej Resurrexit na chór i orkiestrę, Messe selennelle (1824), Te Deum na tenor, trzy chóry i organy, wreszcie monumentalna, wielka msza za zmarłych: Requiem na tenor, chór i orkiestrę (oprócz podstawowej, cztery dodatkowe orkiestry). Jak widać, Berlioz stosował w swoich kompozycjach masywną obsadę, starając się osiągnąć najbogatsze kolorystycznie efekty brzmieniowe.

W tym kontekście chciałbym przywołać także postać Stanisław Moniuszki, który jest czołowym przedstawicielem polskiej muzyki religijnej w tym czasie. Przez wiele lat pełnił funkcję organisty w kościele św. Jana w Wilnie, dlatego też w tym czasie skomponował wiele utworów muzyki religijnej. Obejmują one msze, motety, psalmy, litanie, pieśni i in. 
Moniuszko skomponował 7 mszy ( 3 z tekstem łacińskim, 4 z polskim będącym poetycką parafrazą tekstów mszalnych). Polską twórczość mszalną reprezentują 2 msze na chór żeński z organami (a-moll na dwa głosy, e-moll na trzy głosy) do tekstów E. Odyńca, Msza żałobna d-moll „Pieśni żałobne do Mszy św. za dusze zmarlych" do tekstów A. Felińskiego na chór mieszany z organami (nota bene mszę tę napisał Moniuszko po śmierci swojej umiłowanej matki w 1850 roku), oraz tzw. Msza Piotrowińska na chór mieszany z organami do tekstów J. Wojewódzkiego. Na czoło całej twórczości mszalnej Moniuszki wysuwa się okazała Msza Es-dur (na chór mieszany z organami i kwintetem smyczkowym), najdoskonalsza pod względem formy i najgkębsza w wyrazie.

Ponadto spod jego pióra wyszły jeszcze: 4 litanie ostrobramskie (z tekstami łacińskimi) na cztery głosy solowe $\mathrm{i}$ chór mieszany $\mathrm{z}$ orkiestrą symfoniczną (różnią się pod względem formy i wyrazu: druga ma charakter liryczny, trzecia dramatyczny, czwarta monumentalny), kantata religijna Requiem aeternam na jedenaście głosów, chór mieszany i orkiestrę, szereg utworów na głosy solowe, chór i organy (np. Ecce lignum crucis), utwory na chór mieszany z towarzyszeniem organów (np. znane Ojcze nasz i Pozdrowienie anielskie), hymny i pieśni solowe z towarzyszeniem organów (np. O Panie, co losy ludzkości), Laudate Dominum na sopran i alt z towarzyszeniem fortepianu i in.

\section{WSPÓŁCZESNOŚĆ}

Na koniec sięgnę do sylwetki współczesnego, żyjącego w Krakowie kompozytora i muzyka, Juliusza Łuciuka, który w pewnym momencie swojego twórczego życia właściwie zanurzył się całkowicie w twórczości muzyki religijnej. Sam Łuciuk swoje kompozytorskie zaangażowanie w sferę sacrum komentuje następująco: „Twórczość religijna jest ważnym nurtem mojej działalności kompozytorskiej. Wynika z wewnętrznej potrzeby i jest wyrazem humanistycznego widzenia sztuki i jej oddziaływania na świat w sferze ideałów dobra, miłości i prawdy”. Innym razem mówi: „Muzyka jest moim wyznaniem wiary, wewnętrzną potrzebą podzielenia się wiarą w Boga z innymi ludźmi, dlatego tematy religijne podejmowałem bardzo często"s.

Podstawą wielu utworów Łuciuka stał się chorał gregoriański: „Po pierwsze - mówi kompozytor - inspiracja chorałem gregoriańskim wypływa z mojej fascynacji nim, jako niezwykłym zjawiskiem w historii rozwoju muzyki. Jestem pełen podziwu dla doskonałości jego melodyki. Po drugie śpiewy chorałowe były wykonywane w wielkich przestrzeniach kościelnych, klasztornych, o dużym pogłosie. W tych specyficznych warunkach akustycznych śpiewy brzmiały niezwykle, bo towarzyszył im duży pogłos kolorystyczny. W moich kompozycjach opartych na chorale staram się te warto-

${ }^{4}$ G. Stanek-Peszkowska, Z dala od światel jupiterów. Rozmowa z Juliuszem Łuciukiem w 45-lecie pracy artystycznej, „Ruch Muzyczny”, 26 (24 grudnia 2000), s. 12.

${ }^{5}$ A. Wy szyń ska, Wywiad z Juliuszem Euciukiem, „Niedziela Ogólnopolska” 49(2004). 
ści - brzmienia przestrzennego, kolorystycznego śpiewanego chorału - wydobyć i poszerzyć. Po trzecie - muzyka współczesna ostatnich czasów osiągnęła swoje apogeum w poszukiwaniu nowej materii muzycznej, sięgając po wszelkie środki muzyczne, techniczne i elektroniczne. Naturalną więc reakcją jest szukanie przez twórców przeciwwagi w prostocie. Dla mnie tkwi ona w chorale gregoriańskim, w jego szlachetnej, wysublimowanej melodyce, pełnej prostoty i doskonałego piękna"

Pod wpływem wspomnianej przez kompozytora fascynacji chorałem gregoriańskim powstała w 1974 roku Missa gratiarum actione czyli Msza dziękczynna na chór mieszany. Jest to kompozycja 5-częściowa, zawierająca części stałe mszy: Kyrie eleison, Gloria in excelsis, Credo in unum Deum, Sanctus oraz Agnus Dei $i^{7}$. Mszę swoją zadedykował Łuciuk Bogusławowi Grzybkowi, założycielowi i kierownikowi krakowskiego Akademickiego Chóru „Organum”. Ten sam zespół dokonał prawykonania utworu. Odbyło się ono 22 września 1974 roku w Bazylice Serca Jezusowego w Warszawie ${ }^{8}$. Ciekawym zjawiskiem jest zastosowanie w Credo in unum Deum elementów melodyki z Bogurodzicy - średniowiecznej pieśni polskich rycerzy ${ }^{9}$.

Niemniej ciekawe są Partes Variabiles - to cykl pięciu części zmiennych mszy na chór chłopięcy lub żeński, powstały w 1985 roku. Juliusz Łuciuk omawia następująco przeznaczenie utworu: „Jest to utwór do wykonania estradowego lub w czasie mszy. Są to bowiem - jak tytuł wskazuje części zmienne mszy: na rozpoczęcie mszy, na alleluia, na ofiarowanie, na komunię i na błogosławieństwo. Tekst stanowią łacińskie fragmenty psalmów" ". Tekst poszczególnych części został więc zaczerpnięty z Biblii, a dokładnie z fragmentów łacińskich tekstów Listu św. Pawła Apostoła do Efezjan - Implemini Spiritu Sancto (Napetniajcie się Duchem Świętym - ad introitum), a także psalmów: Ps 31(30) - Alleluja - In te speravi, Domine (Pokładam ufność w Tobie, Panie), Ps 103(102) - Benedic anima mea Domino (Błogosław duszo moja Pana - ad offertorium), Ps 96(95),8 - Tollite hostia (Nieście ofiary - ad communionem) oraz Ps 96(95),7 - Afferte Domino, patriae gentium (Oddajcie Panu, rodziny narodów - ad benedictionem).

Inspiracją do napisania kolejnego utworu, który chcę zaprezentować, stał się tekst Hymnu o miłości św. Pawła z 13 rozdziału Pierwszego Listu do Koryntian w poetyckim opracowaniu Marka Skwarnickiego. Jest to Hymnus de Caritate - kompozycja 12-głosowa (sopran I, II, III, alt I, II, III, tenor I, II, III, bas I, II, III), powstała w 1976 roku.

${ }^{6}$ J. Łuciuk, Z wypowiedzi w audycji Muzyka zwierciadlem duszy, prowadzonej przez Jerzego Stankiewicza w Radiu Mariackim (Kraków, 6 marca 1994).

${ }^{7}$ Por. G. Majka, Przemiany języka dźwiękowego w twórczości Juliusza Łuciuka, Kraków 2007 (praca magisterska, Czytelnia Akademii Muzycznej w Krakowie), s. 165.

${ }^{8}$ Por. tamże, s. 22.

${ }^{9}$ Por. tamże, s. 165.

${ }^{10} \mathrm{~J}$. Łuciuk, Twórczość chóralna w odniesieniu do twórczości ogólnej. Wypowiedź wygłoszona podczas sympozjum chórów w Legnicy (czerwiec 1989 rok; rękopis w archiwum kompozytora). 
Miłości poświęcił św. Paweł cały 13 rozdział listu, w którym mówi ogólnie o miłości w relacji do Boga i do ludzi. Egzegeci dzielą Hymn o miłości na trzy części. W pierwszej (1 Kor 13,1-3) Apostoł przedstawia miłość jako konieczny warunek, bez którego wszelkie dary są bezwartościowe. Wymienia więc charyzmaty: dar języków, proroctwo, znajomość tajemnic i wiedzę, podkreślając, że bez miłości ich posiadanie nic nie znaczy. Również wiara, nawet taka, która czyni cuda, bez miłości nie ma żadnego znaczenia. Kolejny werset dotyczy charyzmatu wspomagania oraz poświęcenia własnego ciała, które bez miłości nie liczą się jako dobre uczynki, jeśli motywem do działania na rzecz potrzebujących jest jedynie próżność i żądza sławy ${ }^{11}$.

$\mathrm{W}$ drugiej części hymnu za pomocą personifikacji autor wymienia poszczególne przymioty miłości, ukazując je w sposób pozytywny i negatywny, dochodząc do stwierdzenia, że „miłość nigdy nie ustaje”. Poszczególne dary Ducha Świętego są ważne w życiu doczesnym, jednak w przyszłości eschatologicznej staną się zupełnie zbędne. Tylko miłość będzie trwać nadal ${ }^{12}$.

W trzeciej części Paweł uzasadnia trwały charakter miłości. Wyjaśnia, dlaczego miłość, w odróżnieniu od innych charyzmatów, będzie trwać wiecznie. Następnie w formie autobiograficznej przeciwstawia wiek dziecięcy dojrzałemu. Na wzór człowieka, który stawszy się dorosłym, przestaje myśleć jak dziecko, próbuje uświadomić Koryntianom, że powinni „wyzbyć się upodobań dziecięcych" i zamiast poszukiwać charyzmatów przynoszących chwałę doczesną, starać się o wzrost miłości ${ }^{13}$. Nasze doczesne poznanie Boga porównuje do oglądania jakiegoś przedmiotu w lustrze, który nigdy nie będzie realnym przedmiotem. W podobny sposób na ziemi oglądamy w stworzeniach jedynie niedoskonałe odbicie Boga. Dopiero poznanie Go w ostatecznej przyszłości będzie doskonałe ${ }^{14}$.

Hymn kończy się stwierdzeniem, że wszystkie trzy cnoty: wiara, nadzieja i miłość są ważne, jednak dwie pierwsze po paruzji staną się niepotrzebne. Stwierdzenie to nie kwestionuje wartości wiary i nadziei, jednak jeśli człowiek osiągnie życie wieczne, którego oczekiwał, przestanie żyć nadzieją. Również wiara okaże się zbyteczna w bezpośrednim kontakcie z Bogiem. Miłość natomiast pozostanie na zawsze ${ }^{15}$.

Ogromne znaczenie miała inspiracja polskim papieżem - Karolem Wojtyłą - Janem Pawłem II. O tym inspirującym wpływie świadczą np. dedykacje, jakimi kompozytor opatrywał liczne swe utwory, czy też fakt częstego sięgania do poetyckich tekstów autorstwa Jana Pawła II lub też wcześniejszych - Karola Wojtyły. Łuciuka fascynowała jego liryczna wrażliwość, wy-

\footnotetext{
${ }^{11}$ Por. J. Czerski, Pierwszy list do Koryntian, Wrocław 2009, s. 605-607.

${ }^{12}$ Por. Komentarz praktyczny do Nowego Testamentu, red. L. Stachowiak, t. 2, Poznań - Kraków 1999, s. 153.

${ }^{13}$ Por. Międzynarodowy komentarz do Pisma Świętego, red. W. Chrostowski, Warszawa 2000, s. 1478-1479.

${ }^{14}$ Por. Komentarz praktyczny do Nowego Testamentu, dz. cyt., s. 153.

${ }^{15}$ Por. Międzynarodowy komentarz do Pisma Świętego, dz. cyt., s. 1479.
} 
czucie słowa, ludzka empatia i zawsze wyczuwalna bliskość Boga. Grzegorz Majka w czasie jednego $\mathrm{z}$ sympozjów poświęconych polskiemu papieżowi mówił: „Jan Paweł II to nie tylko człowiek wraz ze wszystkimi jego cechami osobistymi i poetyckim talentem. To także głowa Kościoła katolickiego, współczesny apostoł narodów, a dla Polaków - niezwykły «ambasador» w świecie i orędownik w niebie. Nadzieja dla narodu, skrępowanego polityczno-społecznymi mechanizmami komunizmu. I właśnie ta wielka łaska mocy i optymizmu, jaka stała się udziałem Polski 16 października 1978 roku, wpłynęła na twórczość Juliusza Łuciuka w sposób fundamentalny. Radosna, ożywcza nadzieja: tak można by określić ten rodzaj inspiracji”"16.

Do najwcześniejszych utworów - owoców owej inspiracji - należy Pieśń Nadziei o Papieżu Stowiańskim z 1978 roku, do fragmentów wiersza Juliusza Słowackiego Pośród niesnasek Pan Bóg uderza. Bezpośrednim impulsem napisania tej 4-głosowej, na chór mieszany oraz sopran, kompozycji był - jak mówi kompozytor - wybór kardynała Wojtyły na papieża. Dzieło to cechuje formalna prostota. Homofoniczna faktura o charakterze chorałowym prowadzona jest konsekwentnie, nawiązując do techniki nota contra notam ${ }^{17}$. Sam Łuciuk tak mówi o swoim utworze: „Kompozycja ma charakter majestatycznej, radosnej pieśni dwuczęściowej z powtarzającym się refrenem o bogatej kolorystyce brzmień harmonicznych. Prawykonanie miało miejsce w Katedrze na Wawelu w czasie pierwszej wizyty Ojca Świętego. Śpiewał chór Organum. Utwór ten ma w swoim programie również Schola Cantorum Gedanensis"18.

Nie mniej ważną inspiracją dla Łuciuka była tematyka maryjna. Jej owocem była, powstała w 1983 roku, Suita Maryjna na chór mieszany do fragmentów Litanii polskiej autorstwa ks. Jana Twardowskiego.

Suita Maryjna składa się z pięciu części, których tekst stanowi pięć spośród trzydziestu dwóch inwokacji do polskich Madonn, wchodzących w skład zbioru zatytułowanego Litania polska. Zbiór Jana Twardowskiego powstawał sukcesywnie, a ostatecznie zawierał dziewięćdziesiąt trzy inwokacje $^{19}$, jednak podczas pracy Juliusza Łuciuka nad Suita Maryjna było ich dopiero trzydzieści dwie. Charakter Suity Maryjnej oddaje istotę liryki ks. Twardowskiego: „Nie sposób interpretować tej muzyki Łuciuka inaczej, niż jako pełen prostoty zachwyt" ${ }^{\prime 20}$. Powtarzające się w utworze zawołanie: „módl się za nami” jest przepojone optymizmem, który - według ks. Twardowskiego - jest nieodłączny od prawdziwej, żywej wiary chrześcijańskiej ${ }^{21}$.

\footnotetext{
${ }^{16}$ G. Majka „Ożywcza świeżość” inspiracji. Pontyfikat Jana Pawła II a twórczość Juliusza Łuciuka (referat wygłoszony podczas sesji naukowej „Muzyka wobec poezji i nauczania Karola Wojtyły i Jana Pawła II; Akademia Muzyczna w Krakowie, 5 listopada 2010).

17 „Nuta przeciw nucie” - rodzaj techniki kontrapunktycznej, polegający na prowadzeniu dwóch lub więcej głosów w tych samych (często równych) wartościach rytmicznych.

${ }^{18} \mathrm{~J}$. Łu ciuk, Twórczość chóralna w odniesieniu do twórczości ogólnej, dz. cyt.

${ }^{19}$ Por. Ksiadz Jan Twardowski, Polska Litania, red. J. Skw ara, Katowice 2003, s. 198.

${ }^{20}$ G. Majka, Przemiany języka dźwiękowego w twórczości Juliusza Łuciuka, dz. cyt., s. 171.

${ }^{21}$ Por. tamże, s. 173.
} 
Suita jest cykliczną formą muzyczną złożoną z kilku (czasem nawet kilkunastu) części o charakterze tanecznym, utrzymanych w tej samej tonacji (z ewentualną zmianą trybu: dur na moll bądź odwrotnie). Poszczególne części suity zestawiano obok siebie na zasadzie kontrastu pod względem metrorytmiki i agogiki. Integralność całej formy podkreślano natomiast za pomocą wspólnego materiału melodycznego ${ }^{22}$. Zgodnie z powyższymi normami, Juliusz Łuciuk zróżnicował poszczególne części Suity Maryjnej, przyznając kolorystyce nadrzędną rolę nad pozostałymi elementami dzieła muzycznego.

Część pierwsza zaczynająca się od słów: Misjonarko Starowiejska opisuje wizerunek Matki Bożej Miłosierdzia. Cudowny obraz, znajdujący się w Starej Wsi, składa się z dwóch części. Dolna przedstawia zaśnięcie Najświętszej Maryi Panny w otoczeniu apostołów, górna - Jej powitanie w niebie przez Chrystusa $^{23}$. Obraz emanuje pięknem artystycznym i powagą, czemu daje wyraz w swym muzycznym ujęciu Juliusz Łuciuk. Głosy chóralne operują łagodnie falującą melodyką i delikatnie zarysowaną, kołysankową rytmiką. Całość prowadzona jest $\mathrm{w}$ taki sposób, iż „poszczególne głosy nienachalnie wyłaniają się z brzmieniowego całokształtu, rozjaśniając jego koloryt, to znów czyniąc go ciemniejszym, stonowanym" ${ }^{24}$.

Smagła góralka z części drugiej - to figura Królowej Tatr, znajdująca się na skraju Rusinowej Polany. Muzyka tej miniatury posiada zupełnie inny charakter niż część poprzednia. Radosny nastrój podkreśla szybkie tempo i wokalnie wykonywane ostinatowe $d z y n ́, d z y n ́, d z y n ́, d z y n ́ . . .$, imitujące dźwięk dzwoneczków. Melodyka zaczerpnięta została z muzyki góralskiej. Podstawą faktury jest prowadzenie równoległych współbrzmień. W przypadku figury ostinatowej są to równoległe kwinty, natomiast w podhalańskich stylizacjach fraz $\mathrm{z}$ tekstem - równolegle przesuwane współbrzmienia tercjowo-akordowe $\mathrm{e}^{25}$.

O Matce Bożej Bolesnej z trzeciej części suity, przebitej siedmioma mieczami, z twarzą zalaną łzami, abp Karol Wojtyła powiedział: „Tyle dyskretnego wyrazu cierpienia i macierzyństwa... Matka Boża Bolesna pod Krzyżem tylko stoi, trwa. Chrystus jest wysoko. Ona trwa, ale stojąc, pomaga w dziele Odkupienia... bo cierpi z Odkupicielem, a Jej macierzyńskie serce przeszywa miecz boleści” ${ }^{\text {"26 }}$. Muzyczna wizja Bolesnej - trzeciej części suity, podkreślona sugestią kompozytora dotyczącą wykonania (doloroso boleśnie, żałobnie) - to jego wizja Stabat Mater. Na tle wyciszonej dynamiki i mormorandowego prowadzenia basów oraz tenorów - wyłaniają się soprany ukazane dwukrotnie ze szczególną intensywnością. Całość utrzymana jest w smętnym, kontemplacyjnym nastroju ${ }^{27}$.

\footnotetext{
${ }^{22}$ Por. Encyklopedia Muzyki, red. A. Chodkowski, Warszawa 1995, s. 856.

${ }^{23}$ Por. Z dawna Polski Tyś Królowa, red. P. Anzulewicz, Szymanów 1983, s. 151.

${ }^{24}$ G. Majka, Przemiany języka dźwiękowego w twórczości Juliusza Łuciuka, dz. cyt., s. 172.

${ }^{26}$ Ksiądz Jan Twardowski, Polska Litania, dz. cyt., s. 23.

${ }^{27}$ Por. G. Majka, Przemiany języka dźwiękowego w twórczości Juliusza Łuciuka, dz. cyt., s. 173 .
} 
Wizerunek Jasnogórskiej Pani z Częstochowy ma szczególne znaczenie dla całego narodu polskiego. Tym bardziej nie mogło zabraknąć w suicie inwokacji: Co Jasnej bronisz Częstochowy u Juliusza Łuciuka - częstochowianina. Ta 4-głosowa część rozpoczyna się chóralnym tutti. Melodyka nawiązuje do średniowiecznych śpiewów rycerskich. Kompozytor posługuje się tutaj opartą na 2-taktowym temacie techniką imitacyjną, która w punkcie kulminacyjnym przechodzi w śpiew homofoniczny, unoszący się w progresji. Całość jest utrzymana w podniosłym nastroju. Ostatni wers: „módl się za nami” ma charakter pokornej, litanijnej prośby, podkreślonej przez opadającą linię melodyczną, augmentację $e^{28}$ rytmu oraz znacznie obniżoną dynamikę ${ }^{29}$.

Ostatnią część Suity Maryjnej stanowi inwokacja: Piękna Patniczko. Kopia obrazu Matki Bożej Częstochowskiej znana jako Matka Boża Pątniczka, z inicjatywy kard. Stefana Wyszyńskiego nawiedziła wiele tysięcy kościołów i kaplic w Polsce ${ }^{30}$. Muzyka tej części opiera się na rytmie poloneza. Melodyka prowadzona początkowo w stylu niemal recytatywnym, zmienia się w coraz bardziej urozmaiconą. Ostatnie zawołanie „módl się za nami” powtarza się wielokrotnie w różnych opracowaniach. Całość przepojona jest radosnym optymizmem ${ }^{31}$.

O ziemio polska to pieśń chóralna, której początek dały słowa papieża Jana Pawła II wygłoszone podczas przemówienia powitalnego na warszawskim lotnisku Okęcie 8 czerwca 1987 roku, tj. pierwszego dnia jego trzeciej pielgrzymki do Polski: „O ziemio polska! Ziemio trudna i doświadczona! Ziemio piękna! Ziemio moja! Bądź pozdrowiona”. To kolejny utwór patriotyczny w twórczości Łuciuka, którego „wielka siła wyrazu tkwi w prostocie melodyki i pięknie harmonii" 32 .

W 2006 roku powstał kolejny utwór do tekstu autorstwa Jana Pawła II Medytacje nad Księga Rodzaju na progu Kaplicy Sykstyńskiej. Libretto utworu stanowi druga część Tryptyku rzymskiego ${ }^{33}$. „Swymi medytacjami objął poeta - a za nim kompozytor - człowieka w postaci najdoskonalszej; człowieka jako przejrzysty i przeczysty obraz Boga Stwórcy" ${ }^{\text {"34. }}$.

O freskach oglądanych w Kaplicy Sykstyńskiej Jan Paweł II mówi, że są efektem geniuszu ludzkiego, który przyoblekł prawdy wiary w kształt malarskiego piękna: „Dlatego ściany Kaplicy Sykstyńskiej wywołują w nas wyznanie wiary w Boga, Stworzyciela wszystkich rzeczy widzialnych i nie-

\footnotetext{
${ }^{28}$ Augmentacja - powiększenie (najczęściej podwójne) wartości rytmicznej wszystkich dźwięków.

${ }_{29}$ Por. G. Majka, Przemiany języka dźwiękowego w twórczości Juliusza Łuciuka, dz. cyt., s. 173.

${ }^{30}$ Por. Ksiądz Jan Twardowski, Polska Litania, dz. cyt., s. 71.

${ }^{31}$ Por. G. Majka, Przemiany języka dźwiękowego w twórczości Juliusza Łuciuka, dz. cyt., s. 173.

${ }^{32}$ Tamże, s. 176.

${ }^{33}$ Por. tamże, s. 251.

${ }^{34}$ G. Majka „Ożywcza świeżość” inspiracji. Pontyfikat Jana Pawła II a twórczość Juliusza Łuciuka, dz. cyt.
} 
widzialnych. Równocześnie zaś wywołują wyznanie wiary w Chrystusa Zmartwychwstałego, który przyjdzie sądzić żywych i umarłych"35. Dalej papież mówi, że „Michał Anioł przenosi piękno widzialne i cielesne na samego niewidzialnego Stwórcę" "36.

Tekst Medytacji rozpoczynają słowa św. Pawła z mowy na Areopagu: „W Nim żyjemy, poruszamy się i jesteśmy”. Po nich następuje refleksja na temat istoty tych słów. Następnie przywołany zostaje biblijny obraz stworzenia człowieka, a po nim realizacja „odwiecznego widzenia Stwórcy” poprzez malarstwo Michała Anioła. Po refleksji na temat Apokalipsy i Sądu przychodzi czas na finał - pełen radości i wiary w spotkanie z Bogiem.

W tej części poematu Jana Pawła II elementem, który zainspirował Juliusza Łuciuka najsilniej, stała się aura ponadczasowości. Majestat historycznej doniosłości wydarzeń, których niemym świadkiem stały się ściany Kaplicy Sykstyńskiej; wielkość genialnej sztuki w postaci fresków Michała Anioła; boskość wyobrażonych nimi scen, a ostatecznie - ranga samej poezji. Ranga z jednej strony literacka, z drugiej - teologiczna i filozoficzna, ale ponad to wszystko - wyrazowa, duchowa. Ta opiera się - ni mniej, ni więcej - o istotę tytułowych medytacji. To medytacyjność zdeterminowała formę, obsadę, motywikę utworu.

„Dotąd nie wyszła spod ręki Juliusza Łuciuka kompozycja, z którą czteroczęściowe Medytacje nad Księga Rodzaju na progu Kaplicy Sykstyńskiej byłyby artystycznie jakoś bliżej pokrewne"37. Ta obszerna, niemal dwugodzinna kompozycja została powierzona zaledwie trzem partiom wykonawczym: mezzosopranowi, barytonowi oraz fortepianowi. Kantylenowa melodyka partii wokalnych podąża za poetyką tekstu. Natomiast w partii fortepianu, określonego w partyturze mianem „kolorystyczny”, kompozytor pobudza wyobraźnię wykonawcy, stosując takie określenia jak: „Sygnały kosmosu”, „błyskawice” czy „powiew tchnienia Bożego"38.

Inspirację taktami biblijnymi widzimy $\mathrm{w}$ dziele skomponowanym w 1985 roku, określanym jako „chóralna symfonia” - Apocalypsis. Przeznaczone jest ono na chór mieszany i kwartet solistów: sopran, alt, tenor oraz baryton $^{39}$. W dziele tym Łuciuk po raz pierwszy wykorzystał tekst biblijny Apokalipsy św. Jana, jednej z najbardziej tajemniczych ksiąg Nowego Testamentu. Jej adresatami są chrześcijanie Azji Mniejszej, których życie staje się coraz trudniejsze na skutek prześladowań. Potrzebują zatem duchowego wsparcia, a takie daje im św. Jan Apostoł. Treść objawienia Bożego, którego był świadkiem, przekazuje nie tylko swoim współwyznawcom, ale

\footnotetext{
${ }^{35}$ Jan Paweł II, Kaplica Sykstyńska mówi o wielkości Boga, s. 259, w: Wokót „Tryptyku Rzymskiego" Jana Pawła II, red. A. M. Wierzbicki, Lublin 2003.

${ }^{36}$ Tamże, s. 261.

${ }^{37}$ G. Majka „Ożywcza świeżość” inspiracji. Pontyfikat Jana Pawła II a twórczość Juliusza Luciuka, dz. cyt.

${ }^{38}$ Por. tamże.

${ }^{39}$ Por. G. Majka, Przemiany języka dźwiękowego w twórczości Juliusza Łuciuka, dz. cyt., s. 198.
} 
i wiernym wszystkich czasów - ukazując losy Kościoła aż do ponownego przyjścia Chrystusa. Występując w Bożym imieniu, autor Apokalipsy ukazuje symboliczne wizje dotyczące „rzeczy ostatecznych”, poucza o przyszłości, a także upomina, grozi lub pociesza. Zasadniczym tematem ostatniej księgi Nowego Testamentu są zatem dzieje ludzkości i Kościoła. Jej głównym przesłaniem jest prawda o ostatecznym tryumfie Kościoła.

Tekst utworu Juliusza Łuciuka stanowi pięć następujących wersów Apokalipsy: „Potem wielki znak ukazał się na niebie: Niewiasta obleczona w słońce i księżyc pod jej stopami, a na jej głowie wieniec z gwiazd dwunastu” (Ap 12,1). „I porodziła syna - mężczyznę, który wszystkie narody będzie pasł rózgą żelazną. I zostało porwane jej Dziecię do Boga i do Jego tronu” (Ap 12,5). „I dano Niewieście dwa skrzydła orła wielkiego, by na pustynię leciała do swojego miejsca, gdzie jest żywiona przez czas i czasy, i połowę czasu, z dala od Węża” (Ap 12,14). „A Wąż za Niewiastą wypuścił z gardzieli wodę jak rzekę, żeby ją rzeka uniosła” (Ap 12,15). „Lecz ziemia przyszła z pomocą Niewieście i otworzyła ziemia swą gardziel, i pochłonęła rzekę, którą Smok ze swej gardzieli wypuścił" (Ap 12,16).

Apocalypsis jest jednym z najważniejszych dzieł wokalnych Juliusza Łuciuka, w którym zastosowane środki muzyczne stanowią doskonałą ilustracje dźwiękową fragmentu ostatniej księgi Nowego Testamentu, ,sugestywnie oddając doniosłość i piękno natchnionego tekstu”40. „Przesłaniem ogólnym kompozycji jest walka dobra ze złem i ostateczne zwycięstwo dobra. Ostatnia część jest apoteozą zwycięstwa dobra nad złem. Prawykonania Apokalipsy dokonała Schola Cantorum Gedanensis na Poznańskiej Wiośnie Muzycznej i śpiewała ją również na festiwalu Vratislavia Cantans. Również wielokrotnie za granicą",41.

W ten wybiórczy sposób starałem się pokazać, jak wielki wpływ na muzykę miała inspiracja religijna. Na zakończenie przytoczę jeszcze raz słowa Juliusza Łuciuka: „Poezja i literatura, tak jak wiara i modlitwa, są nierozłącznie związane $\mathrm{z}$ tym, co piszę. Zawsze ważna i inspirująca była refleksja związana z lekturą Pisma Świętego, tekstów liturgicznych, żywotów świętych czy dokumentów papieskich" "42. Sądzę, że niejeden z twórców na przestrzeni całej historii muzyki mógłby potwierdzić te słowa.

\footnotetext{
${ }^{40}$ Tamże, s. 213-214.

${ }^{41} \mathrm{~J}$. Łuciuk, Twórczość chóralna w odniesieniu do twórczości ogólnej, dz. cyt.

${ }^{42}$ A. Wyszyńska, Wywiad z Juliuszem Luciukiem, „Niedziela. Wydanie Ogólnopolskie" 49(2004).
} 
THE MEANING OF RELIGIOUS INSPIRATION IN MUSIC

\section{Summary}

The issue of religious inspiration in the music is complex and multifaceted, rooted in the vast area of faith (internal, deeply personal) and art. In the present study was undertaken reflection on two kinds of inspiration: biblical, liturgical or religious text in general and sacred music motives and precisely liturgical.

First, a significant source of inspiration is own singing of the Catholic Church Gregorian chant, which in the Middle Ages was the main stream of sacred music, and became a source of development of polyphony, as its cantus firmus. Culmination of the polyphony development was the work of P. Palestrina. From the religious inspiration drew the composers of all eras in the history of music. In the Baroque period developed next to a popular mass such forms as oratory, its particular variant - passion and cantata. Also the form of instrumental music, especially organ (J.S. Bach, J.F. Handel). In the classicism religious music formed mainly three Viennese classicists: J. Haydn, W.A. Mozart and L. van Beethoven. Composed by them religious music bears the features of instrumental music of the period, as well as signs of secular vocal and instrumental music. The composers of the Romantic period are fulfilled in the form of a classical type of cantata mass or a symphony mass. In Poland in the field of religious music marked S. Moniuszko. Nowadays, the example of the composer inspired by religious contents is Krakow composer J. Łuciuk, forming based on Gregorian chant, biblical and liturgical texts, inspired by the person and the pontificate of John Paul II and the Marian theme. He confirms this, saying, "Poetry and literature, as faith and prayer, are inextricably linked with what I write. Always important and inspiring was the reflection associated with the reading of Scripture, liturgical texts, lives of the saints and papal documents".

Keywords:

religious inspiration, faith, art, Gregorian chant, mass, oratorio, passion, cantata, Bible, liturgy 